\title{
Studies on the Clearance and Tubular Reabsorption of Phosphates in Diabetes Mellitus and Some of its Complications
}

\author{
A. Kr. Astrug \\ Internal Therapeutic Clinic, Higher Medical Institute, Sofia, Bulgaria \\ Received October 18, 1965
}

Summary. From a study of the phosphate levels in the serum and urine of 106 diabetic patients and $\mathbf{2 5}$ controls, the following has been established: 1 . Considerably increased renal elimination of phosphates in diabetics manifested by elevated values of the phosphate clearance. 2. Lowered tubular reabsorption of phosphates mainly in patients with different forms of diabetic angiopathy. 3. Retained normal level of the concentration of inorganic phosphorus in the serum, with the exception of its slight increase in patients with diabetic nephropathy.

Études sur la clearance et la réabsorption tubulaire des phosphates dans le diabète sucré et dans quelques unes de ses complications.

Résumé. En explorant 106 malades atteints de diabète et 25 sujets de contrôle, on a établi: 1 . Augmentation considérable de l'élimination rénale de phosphates chez les diabétiques, manifestée par des valeurs élevées des clearances phosphatiques. - 2. Diminution de la réabsorption tubulaire des phosphates surtout chez les malades accusant différentes formes d'angiopathie diabétique. - 3. Niveau normal de la concentration du phosphore inorganique dans le sérum; légère augmentation chez les malades accusant une néphropathie diabétique.

Untersuchungen der Clearance und tubulären Rückresorption von Phosphaten beim Diabetes mellitus und einigen seiner Komplikationen.

Zusammenfassung. Bei der Untersuchung von 106 Diabetikern und 25 Kontrollpersonen konnten folgende Befunde erhoben werden: 1 . Beträchtlich gesteigerte renale Ausscheidung von Phosphaten bei Diabetikern, was sich durch erhöhte Werte der Phosphatclearance feststellen ließ. - 2. Eine herabgesetzte tubuläre Rückresorption von Phosphaten, hauptsächlich bei Patienten mit verschiedenen Formen der diabetischen Angiopathie. - 3. Exhaltene Normalspiegel des anorganischen Phosphors im Serum mit Ausnahme eines leichten Anstiegs der Werte bei Patienten mit diabetischer Nephropathie.
Phosphorus plays an exceedingly important role in the processes of storage, transfer and liberation of energy in the organism as well as in the intermediate metabolism of carbohydrates, fats and proteins. According to recent investigations, phosphorus, in the form of phosphates, passes into the glomerular filtrate of the kidneys from which it is largely reabsorbed together with glucose and amino acids in the proximal tubules (Bland, 1956; Nordin and Fraser, 1960; Maxwely and KuEEMan, 1962). By means of phosphate clearance and the calculated tubular reabsorption of phosphates, it is possible to follow up certain deviations of phosphorus metabolism in different pathological states (LIÈvre and CAMrUs, 1961).

It has been established that after injection of glucose, there is an increased elimination of phosphates in the urine, together with a lowering of their level in the plasma (BLAND, 1956; LEVITAN, 1957; LoTSPEICH, 1959; Martins, 1964). This is due to inhibition of their reabsorption in the tubules. The application of insulin results in a decrease in the phosporus concentration in the plasma, due to increased tissue utilization of carbohydrates (CANTAROW and SCHEPARZT, 1962). On the other hand, when insulin is lacking, the phosphates cannot enter the cells due to the lowered capacity of carbohydrate utilization (GOLDBERGER, 1959). It seems that the phosphate ions and glucose have close or analogous patterns of transportation via the tubular cells (EgGLETon and Schus'ter, 1954) under the effect of the same enzyme systems (Maxwell and KLEEMAN, 1962).

In uncomplicated diabetics, no ehanges have been established in the concentration of phosphates in the urine (Syllaba and Plocma r. 1960) or in the values of the phosphate clearance (LrìvRE and CAMUS, 1961). In diabetic coma the phosphates in the plasma are lowered following the fall of potassium.

The aim of the present paper is to carry out certain comparative studies on the level of phosphorus in the blood serum, and the renal clearance and tubular reabsorption of phosphates in patients with diabetes mellitus and some of its complications.

\section{Materials and Methods}

Investigations have been carried out on a series of 106 diabetic patients and 25 controls (non-diabetics). The patients were left for at least one week on a standard diet containing an almost constant quantity of phosphorus (according to CorvILatr and ABRamow, 1962). The average daily intake of phosphates in the food was $2519 \mathrm{mg}$ for diabetic patients and $2110 \mathrm{mg}$ for the control individuals. In cases being treated with insulin, the test was performed before the administration of the drug. The concentration of phosphorus in the serum was determined photometrically by the Fiske and Subbarow method as modified by GREEXBERG. The phosphate clearance was determined in two 
one-hour clearance periods using the technique described by Lit̀vRe and CAMUs (1961).

The test was made on subjects in a fasting condition and at rest. After emptying his bladder at 8 a.m., the subject drank $0.5 \mathrm{l}$ of water. A blood sample was taken between $8 \mathrm{a} . \mathrm{m}$. and $10 \mathrm{a} . \mathrm{m}$. Urine specimens were obtained at $9 \mathrm{a} . \mathrm{m}$. and $10 \mathrm{a} . \mathrm{m}$., the quantities of both being measured. The phosphorus concentration in the blood and the urine specimens was determined. The tubular reabsorption of phosphates was estimated by means of the clearance of the endogenous oreatinine, which is widely used for the evaluation of glomerular filtration (ToBIAs et al., 1962).

The diabetic patients were divided into the following 5 groups: 15 patients with uncomplicated diabetes, which was verified elinically or in the laboratory $\left(D_{o}\right)$; 21 patients with diabetic acidosis, without elinical manifestations of coma? $\left(D_{a}\right) ; 37$ diabeties with atherosclerosis in the large and medium arteries (aorta, coronary, brain and/or peripheral arteries), established clinically or with the aid of ECG, X-ray or oscillometric methods $\left(D_{s}\right) ; 18$ patients with signs of isolated diabetic retinopathy, without manifestations of renal impairment, i.e. without the obligatory signs and symptoms of diabetic glomeruloselerosis $\left(D_{r}\right) ; 15$ patients with the full clinical picture of diabetic nephropathy $\left(D_{n}\right)$. The mean duration of diabetes in the patients investigated was 6.4 years.

Mean values of blood-glucose levels and excretion of glucose in urine for the different groups are given in Table 1.

Table 1. Mean values of maximal blood-glucose levels (fasting) and maximal excretion of sugar in urine

\begin{tabular}{llllll}
\hline Mean Values* & $D_{o}$ & $D_{\alpha}$ & $D_{s}$ & $D_{r}$ & $D_{n}$ \\
\hline $\begin{array}{l}\text { Blood-Glucose } \\
\text { (mg\%) }\end{array}$ & 289 & $\mathbf{3 8 2}$ & 281 & $\mathbf{3 0 3}$ & 281 \\
Urine-Sugar & 75 & $\mathbf{1 3 6}$ & 40 & 71 & 30
\end{tabular}

Table 2 shows that the concentration of inorganic serum phosphorus presented no substantial changes in diabetic patients compared with controls. Patients

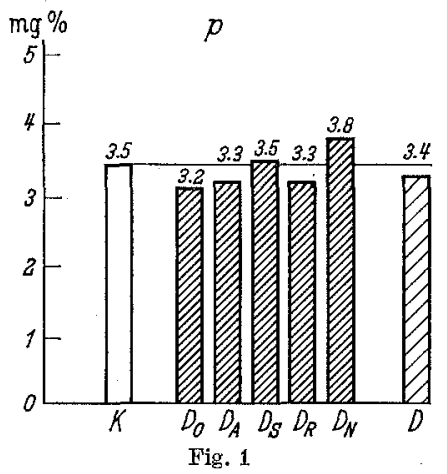

with signs of diabetic nephropathy had the highest mean level, although the difference from the control group is not statistically significant $(t=0.9)$. Hyperphosphatemia was established only in two patients of the $D_{n}$ group. Values of inorganic serum phosphorus between 2 and $3 \mathrm{mg} \%$ were established in 27 diabetics $(25.5 \%)$ and in 8 controls $(32.0 \%)$.

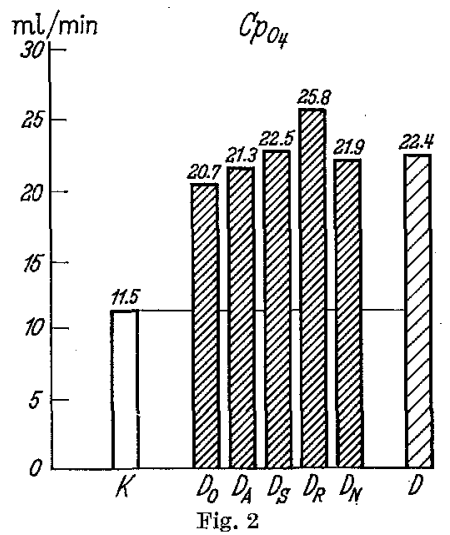

Table 2. Inorganic serum phosphorus in patients with diabetes mellitus, some of its complications and in control individuals

\begin{tabular}{|c|c|c|c|c|c|c|c|}
\hline $\begin{array}{l}\text { Tnorganic } \\
\text { phosphorus } \\
\text { in mg \% }\end{array}$ & $C$ & $D_{0}$ & $D_{a}$ & $D_{s}$ & $D_{r}$ & $D_{n}$ & $D$ \\
\hline Up to 3 & 8 & 4 & 6 & 9 & 5 & 3 & 27 \\
\hline $3.1-5$ & 15 & 11 & 15 & 28 & 13 & 10 & 77 \\
\hline 5.1 and above & 2 & - & - & 一 & - & 2 & 2 \\
\hline Total & 25 & 15 & 21. & 37 & 18 & 15 & 106 \\
\hline Mean value (M) & 3.48 & 3.21 & 3.26 & 3.5 & 3.33 & 3.8 & 3.42 \\
\hline Mean deviation $(\sigma)$ & 0.26 & 0.5 & 0.6 & 0.7 & 0.6 & 1.0 & \\
\hline Mean error (ma) & 0.2 & 0.13 & 0.13 & 0.11 & 0.14 & 0.26 & \\
\hline
\end{tabular}

\section{Results}

The results obtained from testing of serum inorganio phosphorus, phosphate clearance $\left(C_{\mathrm{PO}_{4}}\right)$ and the degree of tubular reabsorption of phosphates (TRP) are presented separately.

The data on inorganie serum phosphorus are given in Table 2 and Figure 1.
The differences observed in studies on phosphate clearance, however, are much more significant. These are shown in Table 3 and Fig. 2.

In each of the groups of diabetics the mean value of phosphate clearance was raised in comparison with the control group. The mean $C_{P_{4}}$ of all the diabetics was approximately twice as high as that of the controls 
(22.4 $\mathrm{ml} / \mathrm{min}$ as against $11.5 \mathrm{ml} / \mathrm{min})$. Patients with diabetic retinopathy showed the highest mean value $(25.8 \mathrm{ml} / \mathrm{min})$. The high statistical significance of the
The results presented give evidence of a considerable lowering of the tubular reabsorption of phosphates in the three groups of diabetic patients with different

Table 3. Phosphate clearance in patients with diabetes mellitus, some of its complications and in control iudividuals

\begin{tabular}{lrrrrrrr}
\hline $\begin{array}{l}\text { Phosphate } \\
\text { clearance } \\
\text { in mI/min }\end{array}$ & $C$ & $D_{o}$ & $D_{a}$ & $D_{s}$ & $D_{r}$ & $D_{n}$ & $D$ \\
\hline Up to 5 & 5 & - & - & 2 & 2 & 1 & 5 \\
$5.1-12$ & 11 & 4 & 7 & 9 & 5 & 3 & 28 \\
$12.1-20$ & 5 & 4 & 3 & 9 & 3 & 3 & 22 \\
$20.1-30$ & 1 & 3 & 5 & 8 & 4 & 4 & 24 \\
Above 30.1 & 2 & 3 & 5 & 10 & 6 & 3 & 27 \\
\hline Total & 24 & 14 & 20 & 38 & 20 & 14 & 106 \\
Mean value (M) & 11.5 & 20.7 & 21.3 & 22.5 & 25.8 & 21.9 & 22.4 \\
Mean deviation $(\sigma)$ & 8.1 & 10.8 & 11.7 & 15.1 & 16.9 & 12.4 & \\
Mean error (m) & 1.6 & 2.9 & 2.6 & 2.5 & 3.9 & 3.3 &
\end{tabular}

Normal values: $5-13 \mathrm{ml} / \mathrm{min}$. (Lì̀vre and Camus, 1961 ), $5.9-17 \mathrm{ml} / \mathrm{min}$. (SCHWARTZ), 1959).

differences between any of the diabetic groups and the control group is evident ( $t$ varies between 2.4 and 3.8, $p$ being less than 0.01 ). No substantial differences were found among the separate diabetic groups. The fact that the mean value of phosphate clearance in patients with diabetic nephropathy was lower than that of patients with diabetic retinopathy, might be explained by the existence of renal insufficiency, where the elimination of phosphorus is impaired, resulting in a retention of serum phosphorus. The blood urea nitrogen was increased in 19 patients from the groups $D_{s}, D_{r}$ and $D_{n}$. No correlation was found between BUN and the phosphate clearance. The mean $C_{\mathrm{PO}_{4}}$ in patients with renal insufficiency was $23.41 \mathrm{ml} / \mathrm{min}$.

No correlation was established between the creatinine and phosphate clearances, nor between the creatinine concentration in the blood plasma and the phosphate clearance.

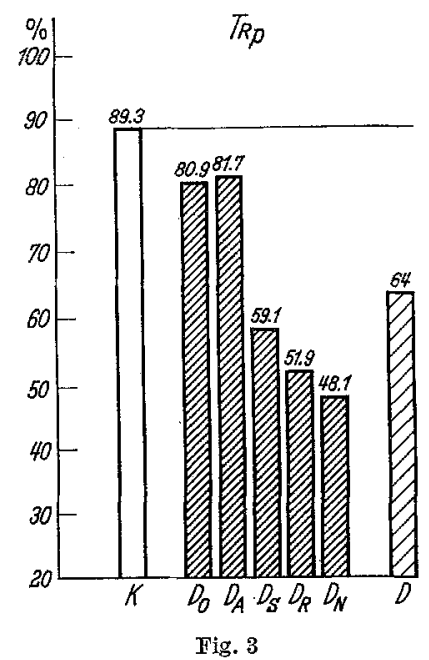

Table 4. Tubular reabsorption of phosphates in patients with diabetes mellitus, some of its complications and in control individuals

\begin{tabular}{lrrrrrrr}
\hline $\begin{array}{l}\text { Tubular reabsorp- } \\
\text { tion of phosphates } \\
\text { in \% }\end{array}$ & $C$ & $D_{o}$ & $D_{a}$ & $D_{s}$ & $D_{r}$ & $D_{n}$ & $D$ \\
\hline Up to 60 & - & - & - & 14 & 6 & 4 & 24 \\
$61-85$ & 5 & 5 & 12 & 11 & 8 & 7 & 43 \\
$86-95$ & 16 & 9 & 7 & 12 & 3 & 2 & 33 \\
96 and over & 2 & - & 2 & 1 & 1 & 1 & 4 \\
\hline T'otal & 23 & 14 & 21 & 38 & 18 & 14 & 104 \\
Mean value (M) & 89.3 & 80.9 & 81.7 & 59.1 & 51.9 & 48.1 & 64.0 \\
Mean deviation $(\sigma)$ & 7.1 & 8.8 & 11.6 & 21.8 & 27.6 & 31.5 &
\end{tabular}

The limits of normal values of TRP vary between 87.7 and $94.9 \%$ (LitrvRE et CAMUS, 1961), $84.7 \pm 0.9 \%$ (CHAMBERs et al., 1956), between 84 and 94\% (PAUPE, 1962), $91.3 \pm 3.3 \%$ (SCHAAF and KYLE, 1954).

We have not observed any case with clinically proved secondary hyperparathyroidism.

Table 4 and Fig. 3 include the data on the mean values of tubular reabsorption of phosphates. forms of diabetic angiopathy $\left(D_{s}, D_{r}\right.$ and $\left.D_{n}\right)$. The greatest decrease was present in patients with diabetio nephropathy. The controls showed a mean value of $89.3 \pm 7.1 \%$, which corresponds to the norms 
indicated above. The differences between the mean values of TRP in the diabetics and the controls are of undoubted statistical significance ( $t$ is of the order of between 2.6 and 7.5, while $p$ is less than $0.01-0.001$ ). Almost $24 \%$ of patients with diabetic nephropathy had TRP values lower than $60 \%$.

\section{Discussion}

The results of the tests carried out provide undoubted evidence of raised renal elimination of phosphates in diabetic patients, including those with normal renal function. The increased elimination, however, did not lead to a lowering of the phosphorus concentration in the blood serum. It would be rather difficult to present a comprehensive explanation of this interesting phenomenon, and its interpretation should be made with great caution. In the most general sense, it could be stated that in diabetic patients the metabolism of phosphorus is disturbed. It could be suggested that in diabetios the interrupted processes of the utilization of carbohydrates in the cells, including the tubular cells, also give rise to certain disturbances in the transfer of phosphates. This might be a result of an exhaustion of the enzymatic systems that play an active part in the oxidative phosphorylation of glucose in the tissues. This is due to the prolonged metabolic disturbance. Obviously phosphates and glucose compete for the same tubular reabsorption pathway (Nordin and Fraser, 1960). Martini has pointed out the importance of the glucose tubular load, with saturation of the tubular reabsorptive capacity for glucose to the detriment of phosphorus. The fact that increased elimination of phosphates takes place even in unaffected kidneys, supports the notion that serious organic lesions of the kidneys are not necessary for this condition.

On the other hand, the lowering of the tubular reabsorption of phosphates is present to a greater degree in diabetics where disturbed renal function has been established. This suggests that additional renal lesions result in further blocking of phosphate reabsorption, thus enhancing the elimination of phosphate (SCHAAF and KYLE, 1954).

It seems most likely that the retention of the normal level of organic phosphorus in the serum of diabetic patients, in spite of its considerable renal elimination, is due to the retained and stable neuroendocrinic regulatory mechanisms, which are very complex processes (YaMSHIRo and ReYNoLDS, 1962). They could restore the chemeostasis of phosphates by using the considerable reserves in bones and tissues. In this respect it would be of interest to investigate further the morphology and function of the parathyroid glands in the different forms of diabetes mellitus and to examine the osteosporotic changes in the bones of the same patients.
HoDGknsson (1961) has found raised values of phosphate clearance and decreased tubular reabsorption of phosphates in 8 out of 10 patients with proved hyperparathyroidism. The adminstration of parathyroid hormone caused an increase of urinary phosphate due to an increase of GFR and a decrease of TRP (Goldmart et al., 1954).

\section{References}

BLand, J.: Clinical Recognition and Management of Disturbances of Body Fluids. Philadelphia and London: Saunders, p. $376-400,1956$.

Cartarow, A., and B. Schepartz: Biochemistry, 3rd ed., Philadelphia and London: Saunders, p. 644-653, 1962. Chambers, E., C. Gordon, S. Goldman and E. ReifenSTEIN: Tests for Hyperparathyroidism: Tubular Reabsorption of Phosphate, Phosphate Deprivation and Calcium Infusion. $\bar{J}$. clin. Endocr. 16, 1507-1521 (1956).

Cervilain, J., and M. Abramow: Some Eiffects of Human Growth Hormone on Renal Hemodynamics and on Tubular Phosphate Transport in Man. J. clin. Invest. 41, 1230-1235 (1962).

EgGieton, G., and S. Schuster: Glucose and Phosphate Excretion in the Cat.J. Physiol. 124, 613-622 (1954).

Goldmans, R., S. BAsset and G. DUndar: Phosphorus Excretion in Renal Failure. J. clin. Invest. 3, 16231628 (1954).

Hodgkinson, A.: Renal Phosphate Excretion Indices in the Diagnosis of Hyperparathyroidism. Clin. Sci. 21, $125-132$ (1961).

Levitan, B.: Effect in Normal Man of Hyperglycemia and Glucosuria on Excretion and Reabsorption of Phosphate. J. appl. Physiol. 4, 224-226, (1951).

LIÈvRE, J., and J. CAMUS: Le coefficient d'épuration plasmatique (clearance) du phosphore minéral en clinique. Rev. du Rhumatisme 28, 1-2, 9-16 (1961).

Lotspeich, W.: Metabolic Aspects of Renal Function. Springfield: G. Thomas, p. $15-37,1959$.

Martin,, P.: Phosphorus Excretion in Normal and Diabetic Subjects, Fifth Congress of the International Dia. betic Federation, Toronto, 215, 1964.

Maxweicl, M., and C. Krweman: Clinical Disorders of Fluid and Electrolyte Metabolism. New York, Toronto, London: McGraw-Hill, p. 328-345, 1962.

Nordin, B., and R. Frasme: Assessment of Urinary Phosphate Excretion. Lancet 1960 I, 947-950.

PaUpe, J.: Exploration des parathyroïdes, La Revue du Praticien. 12, 1119-1133 (1962).

Syltaba, J., and M. Lochă̌: Hospodérstvi elektrolitu u úplavice cukrové. Vnitřni Lék. 6, $639-648$ (1960).

SohaAf, M., and L. Kyte: Measurement of Per Cent Renal Phosphorus Reabsorption in the Diagnosis of $\mathrm{Hy}$ perparathyroidism. Amer. J. Med. Sc. 228, 262-268 (1954).

Tobras, J., K. MoLaUGLIN and J. Hoppen: Endogenous Creatinine Clearance: a Valuable Clinical Test of Glomerular Filtration and a Prognostic Guide in Chronic Renal Disease. Now Engl. J. Med. 226, 317-323 (1962).

Yamshiro, H., and T. ReYnolds: Phosphorus Excretion in Normal and Hyperthyroid Subjects with Controlled Phosphate Intake. Metabolism 11, 213-225 (1962).

A. Kr. Astrua, M.D.

Internal Therapeutic Clinic,

Higher Medical Institute,

Georgi Sofiiski Str., 1

Sofia 31, Bulgaria 